\title{
Ákos Krassóy
}

\section{The "House of Fiction"}

\section{Plurality and Essentialism in Dickens' Bleak House}

\begin{abstract}
"Does this mean 'in a world grown alien to it,' the novel will disappear? That it will leave Europe to founder in 'the forgetting of being'? That nothing will be left but the endless babble of grafomaniacs, nothing but novels that come after the history of the novel?"

(Milan Kundera) ${ }^{1}$
\end{abstract}

\section{"ADA'S PROBLEM"}

In Dickens' Bleak House, Ada Clare addresses the following words of entreaty to Richard Cardstone:

I do not quite know how to write what I wish to say next, but I trust you will understand it as I mean it. [...] I most earnestly entreat and beg you to desist. You can do nothing for my sake that will make me half so happy, as for ever turning your back upon the shadow in which we both were born... Pray, pray... let it go for ever. We have reason to know, by this time, that there is no good in it, and no hope; that there is nothing to be got from it but sorrow.

\footnotetext{
${ }^{1}$ Milan Kundera. The Art of the Novel. New York: Grove Press, 1988, p. 19.

${ }^{2}$ Charles Dickens. Bleak House. London: Chapman and Hall \& Henry Frowde, 1892, p. 605.
} 
She is trying to drag her lover away from the Chancery suit of Jarndyce \& Jarndyce, out of the endless flow of unreconcilable arguments which has determined the lives of the naive parties to the suit as they pursue a breath-taking heritage. A final verdict could certainly change the financial and social standards of those involved. Yet, the words of the quotation speak for themselves: there is no justification for optimism over a quick ending to such an intricate Chancery suit.

This alarming message is addressed not only to Richard, but to the reader, the interpreter as well, who thus is likely to become a victim of the destructive underworld of the novel. The grey setting of the Court of Chancery affects the consciousness of those who pursue meaning as well. It blocks the mind of all those who wish to give a transparent reading to such an opaque sequence of facts. The underlying structure of this micro-world cannot be seen. We follow the confusingly interwoven lines of the plot but do not reach the final stage; we do not get to the cause, to the actual fact of crime. We do not get to know the murderer, the unknown promoter of these dark affairs. The unsuccessful investigation produces a metaphorical meaning. ${ }^{3}$ All in vain, we run after a vaguely discernible trail: we gradually lose confidence in achieving a decent reading and tend to think "there is nothing to be got from it."

\section{DICKENS' REALISM}

However, the investigation must be continued, not "let it go for ever." The mere existence of diametrically opposed critical readings calls for further examination. Dickens has been used as a test case by far too many critical schools and exploited by the proponents of various ideologies. Naturally enough, the political aspects of his oeuvre are the most noticeable, since the socio-political connotations of his vision of the world are obvious. The pages on Jo, for instance, are easy to read as a description of the lowest layer of the urban lumpen proletariat, ${ }^{4}$ or, in a different

\footnotetext{
${ }^{3}$ All in all, Bleak House covers the story of an unsuccessful investigation. Neither of the investigators manage to unfold the secret entirely: while Tulkinghorn is killed before revealing his findings, Bucket, who has got to the bottom of the case, fails to prevent the Lady from ending up in a pauper's grave. (Cf. Mihály Szegedy-Maszák. Kubla kán és Pickwick úr. Budapest: Magvetõ, 1982, p. 241.)

${ }^{4}$ Cf. Sándor Rákos. "Elöszó.” In: Charles Dickens. Az örökösök. Géza Ottlik transl. Budapest: Révai Könyvkiadó Nemzeti Vállalat, 1950, p. vii. The foreword of the 1950 Hungarian translation, written by Sándor Rákos, reflects the thoughts of a highly sophisticated, seif-appointed representative of
} 
perspective, identify Jo's world with $19^{\text {th }}$ century bourgeois liberalism. ${ }^{5}$ Dickens has been appropriated by communists, liberals, and conservatives alike on ideological grounds. He provides a fertile ground for political speculation. But let me quote Orwell's famous essay here at length:

And so far as social criticism goes, one can never extract much more from Dickens than this, unless one deliberately reads meanings into him. His whole "message" is one of that at first glance looks like an enormous platitude: If men would behave decently the world would be decent. ${ }^{6}$

And later:

As I said earlier, Dickens is one of those writers who are felt to be worth stealing. He has been stolen by Marxists, by Catholics and, above all, by Conservatives. The question is, What is there to steal? Why does anyone care about Dickens? Why do I care about Dickens?

It is alarming to think of the possibility of literature eventually falling victim to such exclusively political readings. When compared to the arts, politics is a far more direct and outspoken discipline, which, according to some, can hardly match the implicit strangeness of the artistic. Understandably, the predominance of the political may curb the autonomy of the aesthetic. ${ }^{8}$ Inquiries

what now might be considered the "working class." Today it is to some extent amusing to see someone believe in such a grand narrative: "Later, when describing Mr. Rouncewell's factory, the workers of the factory are shown as well. They walk numb, headstrong along the road, with hard steps. The writer does not say more. But one can feel that it is a much greater trial than that of Jarndyce and Jarndyce, which is going into action from the walls of works, factories. It is pursued for the heritage of the millennia, for the material and spiritual wealth of humankind by its right heirs..." (Rákos, p. vii, my translation).

${ }^{5}$ According to Rorty, Marxists have excommunicated Dickens for his being a bourgeois reformer. (Richard Rorty. Contingency, Irony, and Solidarity. Cambridge: CUP, 1989, p. 147.)

${ }^{6}$ George Orwell. "Charles Dickens." In: Stephen Wall ed. Penguin Critical Anthologies: Charles Dickens. Harmondsworth: Penguin, 1970, p. 298.

${ }^{7}$ Orwell, p. 306.

${ }^{8}$ Dickens' fame may be questioned for a number of reasons. And Dickens himself might provide a basis for this. The interpretation of a text must be fully different from the life of its creator, yet, Dickens may fall under suspicion of not being a novelist at the first place but, say, an author of political pamphlets, whose main goal was to "sell" rather than "create." From week to week he straightforwardly addressed the subscribers of a magazine; he thus had to satisfy the needs of his readers in a totally direct way and only in his later years could he enjoy the freedom of artistic liberty. After all, he wrote for a sociologically distinct reading public, which was probably one reason why he achieved such an unequivocal fame. And of course, there are comments that describe 
which use literary analyses to develop philosophical points, and are not concerned with literature, often prove to be politically motivated.

Therefore, when digging up the foundations of Bleak House, "theory" might be excluded from the field of literary analysis. However, in the present essay one of these openly theoretical narratives will be considered: I shall develop a pragmatist reading of the novel. For various reasons, Richard Rorty seems to be an ideal guide to the world of Dickens' novel. Although in his philosophical pragmatism literature is subject to preconceptions, his interpretation of the novel is being carried out in an utterly thought-provoking way. For Rorty not only gives a strictly exterior reading to Dickens' work, but he does so by interpreting another theoretical framework, which is to defend the integrity of the literary work. He primarily relies on Milan Kundera, though he admittedly converts the Czech novelist's Art of the Novel to his own pragmatic credo. By "unpicking the tapestry woven" "by Rorty's "theory" of the novel, there may be an opportunity to disclose the underlying structure of Dickens' art and determine the place of the political in the nexus of literature and philosophy. ${ }^{10}$ If it is his realism that attracts politically determined criticism to his work, then the realism of the late 19th and early 20 th century should be re-examined. In contrast with the usual positivist conception of this notion, I shall attempt to lay bare the hitherto hidden aspects of Dickens' realism. As stated above, "the question is, what is there to steal?"

\section{RORTY'S PRAGMATISM}

Rorty's tenets make up a "theory," which gives a place to the written word within its own boundaries whenever it serves its own needs, for achieving its own goals. $\mathrm{He}$ uses literature for pragmatic purposes, even if he is eager to substitute "theory" for narrative. In other words, Rorty is approaching the novel from a clearly "exterior" position. This, however, should not induce a fierce attack on

him (while acknowledging some of his skills) as a cheap sensationalist, whose oeuvre shows distinguishable disproportionateness. (See, for example: Szegedy-Maszák, p. 234; or other texts in the Penguin Critical Anthology by Kafka [pp. 258ff.], James [pp. 168ff.], Huxley [pp. 281ff.], or Santayana [pp. 259ff.]. Shaw describes him as a "a complete barbarian" [p. 288], not to mention Woolf's infamous "don't cross the street!" speech, of course [pp. 277ff.].)

${ }^{9}$ This is Kundera's image (Kundera, p. 160).

${ }^{10}$ As regards other major Hungarian contributions to this discussion, criticism of Kundera as a writer by Mihály Vajda, Ágnes Heller and Gergely Angyalosi will be left out here, for I will mostly concentrate on arguments against Rorty's theory. 
pragmatism, since Rorty has several arguments to defend his enterprise. There is an essential point, an origo underlying his work that explains the whole system of his thought (along with the peculiar position he prescribes to the novel): his ambition to overcome grand narratives within the limits of his own narrative.

Indeed, a quasi-ethical need ${ }^{11}$ to find a response to the weight modernity imposes on history in the post-Auschwitz era characterises his thought. Thus, as Rorty's philosophical pragmatism inherently stems from a political attitude, in a most natural gesture he borrows Judith Shklar's definition of liberalism to declare his own objective: "... liberals are the people who think that cruelty is the worst thing we do." ${ }^{12}$ And he takes this principle very seriously; his pragmatism is chiefly built on the omnipotence of this maxim: his whole undertaking could be explained by this single line. Rorty sketches the figure of the "liberal ironist," for he

use[s] the "ironist" to name the sort of person who faces up to the contingency of his or her own most central beliefs and desires - someone sufficiently historicist and nominalist to have abandoned the idea that those central beliefs and desires refer back to something beyond the reach of time and chance. Liberal ironists are people who include among these ungroundable desires their own hope that suffering will be diminished, that the humiliation of human beings by other human beings may cease. ${ }^{13}$

So Rorty does everything in the pursuit of a particular goal. In as much as his sole aim and purpose in constructing his "theory" is to reduce pain, he is acting pragmatically. The imaginary individual of his story, defying the sophisticated aspiration of the French Revolution, looks back on history, understands the essential relativity of things and, as a result of this, cuts down on the use of essentialist narratives to the utmost satisfaction of his fellows. Reading Nietzsche and Heidegger may primarily teach one how to view the past and develop the ironic state of mind one may need in order to realise what to do in

\footnotetext{
${ }^{11}$ Rorty quite often describes himself as a something like a Wittgensteinian pragmatist, which might speak for the ethical implications of his work. Rorty himself, however, has always denied the possibility of having such an inclination of his philosophy, when asked at conferences. (A verbal comment from Prof. János Boros.)

${ }^{12}$ Rorty. Contingency, Irony, and Solidarity, p. xv.

${ }^{13}$ Rorty. Contingency, Irony, and Solidarity, p. xv.
} 
real life - how to live well with one's peers. Rorty's vocabulary contains lesser words; 'contingency' leads to 'irony' and ends up in 'solidarity' in the long run.

However, it might be useful to compare Rorty's hero(ine) to the leading characters of other thinkers' tales ${ }^{14}$ as well. For Rorty's tenets make a clear-cut alternative to the current views on the Post-modern; his ideas take shape as a response to the works of proponents of twentieth century social theory. His oeuvre seems to be positioned between the stances taken by the rather culturepessimistic, ethics-oriented French thought and the more confident German line of thinking. On the one hand, "the American"15 does not fully share Lyotard's all-embracing distrust in grand narratives, because, in his view, instead of totally dismissing these discourses one may evade them by going around them. This idea latently comprises two premises at least: first, as a liberal pragmatist, Rorty seems to have confidence if not in the progress, but in the successful functioning of human societies; second, he entertains serious doubts about deconstructive narratives: in his view they seem to idolise new entities in the place of the used ones. For epistemological ${ }^{16}$ and the political reasons mentioned above he does not put much hope in a pure version of postmodernism. Therefore, the deconstructive resources of human thought might be important, but the liberal ironist treats them as simple reminders of certain fallacies in the history of mankind. ${ }^{17}$ He regards the fulfilment of grand narratives, utopias as an endless process - "an endless, proliferating realization of Freedom, rather than a convergence toward an already existing truth."18

So, Rorty does not rage against Modernity. Yet, this is not to say that he would, by learning from the errors of the past for example, reconsider its program. He does not follow Habermas either, as he does not think human societies can profit from history by using educational processes. In the Rorty

\footnotetext{
${ }^{14}$ In many of his writings, Rorty tries to destroy the serious nature of his own text by calling his speech a "tale." Apparently, he attempts to remind his readers of the fact that this is not the only way of treating the issue.

${ }^{15}$ Mihály Vajda's disparaging term for Rorty. (Mihály Vajda. A posztmodern Heidegger. Budapest: TTwins-Lukács Archívum-Századvég, 1993, p. 59.)

${ }^{16}$ Rorty's contempt for essentialism is largely related to his critique of language. In his view, everything depends on the dictionary of the given community. Ascetic priests claim the ineffable by inventing a new vocabulary. (Richard Rorty. Essays on Heidegger and Others. Cambridge: CUP, 1989, p. 72).

${ }^{17}$ See the introduction of Rorty's Essays.

${ }^{18}$ Rorty. Contingency, Irony, and Solidarity, p. xvi.
} 
utopia, knowledge is not obtained from a stable position by reflecting on what has been done before:

In my utopia, human solidarity would be seen not as a fact to be recognized by clearing away "prejudice" or burrowing down previously hidden depths but, rather, as a goal to be achieved. It is to be achieved not by inquiry but by imagination, the imaginative ability to see strange people as fellow sufferers. Solidarity is not discovered by reflection but created. $^{19}$

The pragmatist history after history goes along on its own. Indeed, this concept is not "theoretical" in the usual sense of the word. For it focuses on action - it is a "theory" of action. ${ }^{20}$ In lieu of useless theorising, the point is that people actively co-operate in reducing the negative effects of the system.

And Rorty's political "theory" 21 is strongly motivated by a pragmatic "theory" of knowledge. In his view, this is best exhibited in the functioning of present-day pluralistic bourgeois democracies, in which politics has become a question of sentimental calls for the tempering of suffering instead of moral calls to philosophic perfection. ${ }^{22}$ Democracy will take a preference over philosophy; it is not at all necessary for one to have a typified idea of the main goals of society to act properly in a political community. What society utterly needs in the place of abstract ideas is easily understandable, direct talk that effectively achieves its goals. Rather than giving a concise background to social action, there should be a focus on the know-how of finding a consensus in down-to earth issues, not ignoring the emotional factor at all. ${ }^{23}$

Generally speaking, Rorty does not favour "theory." Firstly, he thinks that the philosophical treaties is not capable of communicating the liberal calling properly. Though reaching the ironic mood by reading thinkers like Nietzsche

\footnotetext{
${ }^{19}$ Rorty. Contingency, Irony, and Solidarity, p. xvi.

${ }^{20}$ Even though the pragmatist can as a matter of fact not have a "theory" of anything, whatsoever.

${ }^{21}$ Certainly, Rorty's tenets on politics cannot be treated as a detailed, conceptual theory of politics debating exact, down-to-earth problems of justice, law, and so on. He does not have a scheme, in the closest sense of the word. He may fit the category of the 'public intellectual,' or the 'social thinker' rather than the philosopher specialist.

${ }^{22}$ Richard Rorty. "Heidegger, Kundera and Dickens." Essays on Heidegger and Others, p. 81.

${ }^{23}$ In Rorty's view, democracy comes ahead of philosophy. Unlike communitarians, he does not think that liberal social theory should be reformed, because it is needless to be familiar with the philosophical background of a democratic principle to practice it (András Lánczi. Huszadik Századi Politikai Filozófia. Miskolc: Fáklya, 1997, p. 173).
} 
and Heidegger can be highly profitable, it is absolutely pointless without implementing their tenets in praxis. Theory has to be made visible, packaged for the inquiring mind. Secondly, philosophers may often make the mistake of locating the essence of the object of their curiosity, which does not (unlike in the natural sciences) assist moral and political reflection. ${ }^{24}$ They try to go behind the surface of words in a strictly not politically correct way. ${ }^{25}$ In the pragmatist's view things are far more complex than that. There are too many stories, which simply cannot be bound together and reduced to a real one. Not to mention that it is, after all, fairly anti-democratic to postulate a group of people who should be closer to something genuine than the rest of people, who know more than "us." Rorty does not seem to be happy with the existence of a cultural elite which holds the key to the underlying issues of mankind. ${ }^{26}$ As opposed to essentialism, Rorty is never searching for something "Wholly Other," 27 and would even sometimes go as far as dismissing theory as such. One should stay on the lookout for the rise of new genres, as perhaps the traditions of anti-theory preserve the capacity to maintain liberal hopes on their own. ${ }^{28}$

\section{RORTY'S "THEORY” OF THE NOVEL - RORTY'S DICKENS}

There are lots of points as to why neo-pragmatism supports the reading of Dickens. Rather than mistaking the genre for being second-rate, the advantages of the novel should be considered over the negative effects of theory on the democratic enterprise. In general, narrative has its own means of realising Rorty's liberal utopia.

${ }_{25}^{24}$ Rorty. "Heidegger, Kundera and Dickens," p. 67.

25 Going for the one right answer might lead to apparent inconsistencies in intercultural comparisons, and cause serious difficulties in the globalising world of our present days.

${ }^{26}$ Rorty. "Heidegger, Kundera and Dickens," p 74.

${ }^{27}$ Rorty. "Heidegger, Kundera and Dickens," p. 71.

${ }^{28}$ Rorty. "Heidegger, Kundera and Dickens," p. 73.

${ }^{29}$ Rorty tries to dismiss the work of philosophers, though he himself is philosophising on the novel. Thus, his project might duly seem ambiguous, and perhaps he is not keen enough on clarifying the confusion. However, the notions used by him can be systematised, which might justify his project. Here is a possible classification of his terminology, from the most "negative" to the most "positive": metaphysics/essentialism (ascetic priests / one, grand narrative) - theory (quasi-essentialist; always trying to find something true) - philosophy (restricts itself and gives way to the novel) - narrative (the pluralism of the novel). 
On the one hand, story telling has proved to be quite effective in educating people's minds through the courses of history. Books have been read by people who "either could not follow a philosophical argument if they tried, or by people who have no wish to try." ${ }^{30}$ It is perhaps preferable to read novelists to find out what went wrong with the Enlightenment rather than the works of socalled philosophers. On account of Kundera, Rorty attributes a large instructive force to social criticism in fiction: it looks as though Flaubert, for instance, did more to overthrow general "stupidity" than anybody else before. ${ }^{3 i}$ Someone who uses a language they understand, writes about topics of their interests - and yet teaches them new things by using latent processes - will be more respected by the common people.

On the other hand, there is a difference in quality, not in terms of effectiveness only. It is relatively easy to line up an opposition between the ascetic priest's inclination for simplicity, structure and abstraction, and the novelist's taste for detail, diversity and accident. ${ }^{32}$ The underlying features - the dissimilarity of viewpoints, or the plurality of the description of the same events, for example - may provide a proper substitute for philosophical dualism, since in contrast to the One True Description the novelist "may move back and forth" between the many possibilities. Due to the implicit humour of the novel, theory will look comical: anyone who could know more than the rest of "us," who would reject all descriptions save one, develops ridicule. ${ }^{34}$ Owing to its form, fiction is a place of tolerance and ultimate truth seeking. ${ }^{35}$ In the carnivalesque of the novel people retain their idiosyncrasies and become individuals. "Everybody can do what they want if they don't hurt anybody else while doing it." Everybody has the right to be understood, yet nobody to rule.

Thus, Dickens, the "social theorist" can be revisited. Rorty prescribes an utterly flattering role to the author of Bleak House:

I want to put forward Charles Dickens as a sort of anti-Heidegger.

[...]For Dickens could help [...] grasp a complex of attitudes which was important to the West, and perhaps unique to the West, in a way that

\footnotetext{
${ }^{30}$ Rorty. "Heidegger, Kundera and Dickens," p. 73.

${ }^{31}$ Rorty. "Heidegger, Kundera and Dickens," p. 76.

${ }^{32}$ Rorty. "Heidegger, Kundera and Dickens," p. 73.

${ }^{33}$ Rorty. "Heidegger, Kundera and Dickens," p. 79.

${ }^{34}$ Rorty. "Heidegger, Kundera and Dickens," p. 73.

${ }^{35}$ Rorty. "Heidegger, Kundera and Dickens," p. 75.

${ }^{36}$ Rorty. "Heidegger, Kundera and Dickens," p. 75.
} 
neither Heidegger nor any other philosopher could. The example of Dickens could help them think of the novel, and particularly the novel of moral protest, rather than the philosophical treatise, as the genre in which the West excelled. ${ }^{37}$

Dickens could well exemplify a counteraction on essentialism. ${ }^{38}$ Similarly to Orwell, Rorty underlines the importance of Dickens' scheme of characters. In his view the most substantial feature of these Victorian novels is the unsubsumable idiosyncrasy of their figures. Dickens' characters refuse to be categorised in moral typologies, but they take the place of moral principles, virtues or vices instead. ${ }^{39}$ As Rorty says, "they do so by permitting us to describe each other as 'a Skimpole,' 'a Mr. Pickwick,' 'A Gradgrind,' 'a Mrs. Jellby,' 'a Florence Sombey." ${ }^{40}$ Rorty envisages a fictional society, which gains its vocabulary from novels through names, rather than from ontotheological or ontico-moral treatises. There the ultimate goal of human social organisation would ironically not be more than comfort, the enjoyment of human association. Thus, one can learn how institutions could be changed so as to best guarantee everybody's rights and duties.

Rorty provides for a few other explicit arguments on the presence of the democratic in Dickens' descriptive art. He relies on Orwell: "The outstanding, unmistakable mark of Dickens' writings is the unnecessary detail [...] he is all fragments, all details, - rotten architecture, but wonderful gargoyles - and never better then when he is building up some character who will later on be forced to act inconsistently." ${ }^{42}$ In Dickens' novels, attention not oniy falls on the protagonists; the viewer is presented a large variety of different sorts of people

\footnotetext{
${ }^{37}$ Rorty. "Heidegger, Kundera and Dickens," p. 68, my italics.

${ }^{38}$ One might want to recall the special circumstances that describe the publication of Pickwick Papers, or other works. People waiting at train stations for the latest editions, or inquiring at American harbours about the outcome of stories already published in series at the other side of the Atlantic were not rare episodes in the birth process of the Dickens cult. Dickens' world had a significant effect on the common consciousness; his character sketches were contributing to reader's sometimes-limited experiences to a large extent. The paperback versions of his books were available to the poorer layers of society thereby taking a large share in people's "education." As stated by Orwell, he has become an institution - "he is there, like the Nelson column" (Orwell, p. 307).

${ }^{39}$ Rorty. "Heidegger, Kundera and Dickens," p. 78.

${ }^{40}$ Rorty. "Heidegger, Kundera and Dickens," p. 78.

${ }^{41}$ Rorty. "Heidegger, Kundera and Dickens," p. 78. See the relevant places in Orwell, too (Orwell, pp. 301-312).

${ }^{42}$ Quoted in Rorty. "Heidegger, Kundera and Dickens," p. 81, my italics.
} 
who follow their own lights. As there are no maxims, except that of equality, in the Dickensian "paradise of individuals" ${ }^{43}$ everybody has an equal right to exist. Moreover, these minor character sketches are just as elaborate as those for characters of higher importance. ${ }^{44}$ Thus, one may most definitely improve in a toleration of diversity if one treats apparent inconsistency not as something to be rejected but as a mark of the inadequacy of our current vocabularies.

It is not surprising to find literal, word-to-word parallels between Dickens' art and Rorty's "theory" of democracy:

Despite having no higher goal than comfortableness of human association, Dickens did an enormous amount for equality and freedom [...]. But Dickens performed his services to human liberty not with the help of the "savage indignation which Swift rightly ascribed to himself but with something more bourgeois - sentimental tears and what Orwell called a generous anger.

While the sentimentality of Dickens' romances is reflected in the watchwords of the pragmatist's anti-theory, Rorty finds a proper model of his fantasy-world in Dickens' writings. In his view - in their view perhaps - social change is not a question of re-creation, but of mutual adjustment. ${ }^{46}$ All in all, the Dickensian phenomenon proves to be perfectly prosaic and democratic at the same time, since it aims to realise the liberal calling by pointing to the weaknesses of the present status quo.

\section{RORTY'S BLEAK HOUSE}

Although the presence of pragmatic principles might be detected in number of layers of Bleak House, I shall deliberately focus on one aspect of the given work only: its images. ${ }^{47}$ Admittedly, Rorty's project requires a special attitude to art in

\footnotetext{
${ }^{43}$ Kundera, p. 159, quoted in Rorty. "Heidegger, Kundera and Dickens," p. 74.

44 “'The generosity of Dickens', Stowe's, and King's anger comes out in their assumption that people merely need turn their eyes toward the people who are getting hurt, notice the details of their pain being suffered, rather than needing to have their entire cognitive apparatus changed" (Rorty. "Heidegger, Kundera and Dickens," p. 80).

${ }^{45}$ Rorty. "Heidegger, Kundera and Dickens," p. 79, my italics.

${ }^{46}$ Rorty. "Heidegger, Kundera and Dickens," p. 80.

${ }^{47}$ In my view, there are at least four distinct levels of the work to be examined besides images, which I, lacking space, shall not expand here: (1) the unique self-constitution of the speaker, (2) the
} 
general. Obviously, a scheme that prescribes the leading role to the novel should necessarily root in an aesthetics that respects the most "anti-artistic" of all literary genres. ${ }^{48}$ Rorty praises the beholder of the funny, the humorous - not that of the beautiful. The ultimate image of Bleak House could be taken as a means of illustration to this statement. When commenting on Nabokov's interpretation of the fog, Rorty turns down Nabokov's aestheticism as a non-pragmatic art "theory." He quotes Nabokov at length:

As is quite clear, the enchanter interests me more than the yarn spinner or the teacher. In this case of Dickens, this attitude seems to me to be the only way of keeping Dickens alive, above the reformer, above the penny novelette, above the sentimental trash, above the theatrical nonsense. There he shines forever on the heights on of which we know the exact elevation, the outlines and the formation, and the mountain trails to get there through the fog. It is in his imagery that he is great. ${ }^{4}$

This is of course unacceptable to Rorty. He must be interested in a Dickens totally unlike Nabokov. What ticks him off is Nabokov's narrow focus on the artistic - the "tingles between the shoulder blades." ${ }^{.50}$ It looks as though Nabokov is solely concerned with the aesthetic bliss of literature ${ }^{51}$ and thinks that the sociological or political content has to be devised for those who are naturally immune to the vibrancy of literature. ${ }^{52}$ In the pragmatist's view, it is much easier to admit that Bleak House aroused participative emotions which assisted in changing the laws of England, and as a result made Dickens immortal. Rorty cannot accept talk in a quasi-metaphysical style about the essential goals of the writer. ${ }^{53}$ Rorty cannot tolerate Nabokov's reading of the fog. The well-known description of the image at the beginning reads as follows:

characteristically strong voice of the narrator, (3) Dickens' liking of showing things instead of telling about them, and (4) the characters themselves could all be used to illustrate the pragmatic inclination of the book.

${ }^{48}$ Fiction has been depreciated as a genre by many authors. (See, for example, Mihail Bakhtin. "Eposz és regény." Az irodalom elméletei III. Pécs: Jelenkor, 1997, pp. 27-68.)

${ }^{49}$ Quoted in Rorty. Contingency, Irony, and Solidarity, p. 148.

${ }^{50}$ Rorty. Contingency, Irony, and Solidarity, p. 147.

${ }^{51}$ Rorty. Contingency, Irony, and Solidarity, p. 147.

${ }^{52}$ Rorty. Contingency, Irony, and Solidarity, p. 147.

${ }^{5.3}$ Rorty. Contingency, Irony, and Solidarity, p. 148. 
Fog everywhere. Fog up the river, where it flows among green aits and meadows; fog down the river, where it rolls defiled among the tiers of shipping and the waterside pollutions of a great (and dirty) city. Fog on the Essex Marshes, fog on the Kentish Heights. Fog creeping into the cabooses of collier-brigs; fog lying out on the yards, and hovering in the rigging of great ships; fog drooping on the gunwales of barges and small boats. Fog in the eyes and throats of ancient Greenwich pensioners, wheezing by the firesides of their wards... Chance people on the bridges peeping over the parapets into a nether sky of fog, with fog all around them, as if they were up in a balloon, and hanging in the misty clouds.

And a few lines below, accented by the personal voice of the narrator:

Never can there come fog too thick, never can there mud and mire too deep, to assort with the groping and floundering condition which this High Court of Chancery, most pestilent of hoary sinners, holds, this day, in the sight of heaven and earth. ${ }^{54}$

Rorty would be entirely satisfied with Nabokov's interpretation of this trope as a means of revivifying the legal miasma that emerges from the dealings of The Chancery. Yet, when it turns out that Nabokov expects one to treat Dickens' attacks on evil as a simple "lesson in style" ${ }^{55}$ (!) and praises Dickens' political skills for their artistic mastery, Rorty cannot go along with Nabokov. In defence of writers who, as described by Nabokov, only create "topical trash," ${ }^{56}$ Rorty does not want to believe in abstract entities. In his view, literary pieces should, rather than enrich the self-centred, autonomous field of art, directly serve the needs of the public.

Thus, the exact artistic mechanism of the work could be considered. Even though the pragmatist can de facto not engage in any kind of "interpretation," Rorty's account of figures could be reconstructed. Ironically, the fog proves to be a par excellence Rorty entity. The fog applies to readers, too. Metaphorically speaking, this figure crosses the boundaries of the work and spreads over things

\footnotetext{
${ }^{54}$ Dickens, pp. 17-18, my italics.

${ }^{55}$ Rorty. Contingency, Irony, and Solidarity, p. 146. At one point, Nabokov cites a famous paragraph on Jo, which begins with "Dead, your Majesty! Dead, my lords and gentleman!" and ends with "And dying around us every day." In Rorty's view, of course, this "is to call public action if anything in Dickens is." But Nabokov tells us that the chapter is "a lesson in style, not in participative emotion." (Nabokov quoted in Rorty. Contingency, Irony, and Solidarity, p. 148.)

${ }^{56}$ Quoted in Rorty. Contingency, Irony, and Solidarity, p. 148.
} 
outside as well. Supplying the medium that conceals things from our questioning eyes, the fog makes it impossible for us to know everything. Just as the unnecessarily detailed presentation and the introduction of a diversity of characters secondary to the main line of the plot halt the narration, the emblematic fog blocks hasty conclusions as to the ultimate mystery of the story. The fog paralyses our readiness for judgement. In a certain sense, it blocks the awareness of the interpreter craving for the reading. The case of Jarndyce and Jarndyce reveals a self-ruling organism, which may seem to be a menacing entity, with all its dusty files, shady conspiratorial bloodshed, and unquestionable implication for all corners of life. However, as a figure of reading prose it does not threaten with any danger. For the reader, the interpreter, it must exemplify the perfect attitude to the text. The artistic repertoire of Bleak House evokes the Rorty concept of the novel: the image reminds us of our mission of democracy. Instead of achieving "the ultimate," the reader has to keep looking around.

Obviously, the language of the novel might provide a suitable base for this, since it renders the debate under the circumstances of a game, the chase after meaning. As the reader is constantly looking for the roots of the overlapping branches of the suit, he/she hopelessly strives to find a solution. Its origin is undetectable. On the one hand, the novel contains the story of an unsuccessful investigation. ${ }^{57}$ Even though Tulkinghorn, Guppy and Bucket become fully aware of the Lady's secret, the general public does not get to know anything about the mystery. Not even Sir Leicester's negative belief in the riddle of his wife, based on the information he received from the investigator, is confirmed. Bucket wisely keeps it to himself, and apart from the rumours spreading around in society nothing comes to light. The long-established practices of the Dedlocks persist. The narrative of a traditional family of England is preserved. Dickens drops a few comments on the upcoming death of the Lord, yet the reader may well finish the book with the confidence that nothing will really change. What has been going on for hundreds and hundreds of years may endure for centuries in the future. The line of the story was not broken; it is continuing towards nothing, so "there is" indeed "nothing to be got from it." The same applies, on the other hand, to the conclusion of the case. The whole book is a report on the proceedings of Jarnayce and Jarndyce. Both the heirs and the reader are

\footnotetext{
${ }^{57}$ See Szegedy-Maszák, p. 24.
} 
continuously following a trail ${ }^{58}$ in hope of a settlement. But, in the concluding chapters of the work, another discovery is made: on account of a ragged piece of paper found in Krook's "archives" every inheritor gets his/her own share from Jarndyce's wealth. However, all of that is consumed by the legal expenses. All the money drawn from the heritage should be spent on the costs of indifferent clerks, officers. Thus, "the suit lapses and melts away," 59 also leaving the true heirs wmpty-handed. The reader does not gain much, at least not in the usual sense of the word. One can, as a matter of fact, understand the main moral of the story. The juridical process was all in vain, and those who financially relied on the case should decay.

In the spirit of pragmatism the identity of assassins, the content of verdicts are neither important. Unlike in a desire-governed, essentialist attitude, no "genuine" ending can be expected here. One cannot satisfy one's hunger for information in the text as in theory - the traditional methods of understanding prove to be too old-fashioned in Rorty's criminology.

\section{BLEAK HOUSE - A BLEAK THEORY OF THE NOVEL?}

In general, Rorty is right in what he says about the democratic nature of the novel. There really is something only the novel can say in its own way. Even when applied to the particular work, his "theory" looks completely plausible. Yet, one should face the consequences such a pragmatist definition has on the concept of (the structure, and, as a result, the philosophy of) narration.

First of all, his principles redefine the work of art. As shown above, the ultimate goal of Rorty is to put the principles of democratic thinking into practice. Therefore, he has to use a special technique. Rorty's work exclusively focuses on the activity of our senses. As opposed to the general roles of telling, the function of seeing is emphasised here. And the visual, the perceptible turns out to be a proper means of demonstration. The reader cannot discern the outcome of the happenings straight away, but is made to watch the whole system patiently.

\footnotetext{
${ }^{58}$ Derrida's concept of the trail in interpretation might have pragmatist connotations, but in fact it has nothing to do with Rorty's project. As mentioned above, Rorty is not fond of deconstruction. To learn more on the issue, see especially Jacques Derrida. "Remarks on Deconstruction and Pragmatism." In: Critchley, Derrida, Laclau \& Rorty. Deconstruction and Pragmatism. London: Routledge, 1996, pp. 13-19. (The book contains Derrida's answer as well.)

${ }^{59}$ Dickens, p. 797.
} 
Rorty's Dickens slows down the flow of events. He aims at depicting things as they are. This way, Rorty embarks on a special conception of the story. In an implicit way, Rorty attempts to eliminate the power of telling. Here emphasis is iaid, not on showing, but on peering as such. Otherwise, one may suspect that the contours of things could be overshadowed by the dynamism of story, which, being a holder of desire, should obviously not meet the requirements of pragmatic thinking. Rorty reinterprets the basic notions of telling. Apparently, such a view on fiction has its own aesthetic premises, and the blame seems to be laid on the primary Aristotelian concepts. Rorty's account of fiction seems to be absolutely in line with the heritage of prose, but it does not fulfil the initial obligations of story telling. While neo-pragmatism attends mostly to the prevalent exhibition of things, it disregards the cardinal quality of reporting events. Probably, there lies a more fundamental mark of Cervantes's project: unaffected, impulsive tale telling. In a superb way, the viewer gets moved by the issues of democracy yet, the main reason of one's attraction to reading is not established: the reader's curiosity as to the events is left out from Rorty's premises. Listening to substantial information makes people interested in the outcome of the case. Nevertheless, the reader feels a compulsive need for the progress and the ending of the plot. In anti-essentialist thinking 'necessity' as such becomes outdated. The motor of the 'plot' should be exterminated.

There may be a doubt as to whether Rorty's thesis can be verified at all. There must be other writings that would not fit this definition. As a result, Rorty's "theory" of the novel might turn out far less universal than his pragmatist arguments may claim it to be. And he admits that. Consider the following:

So the lesson I draw from Proust's example is that novels are a safer medium than theory for expressing one's recognition of the relativity and contingency of authority figures. For novels are usually about people - things which are, unlike general ideas and final vocabularies, quite evidently time-bound, embedded in a web of contingencies. Since the characters in novels age and die - since they obviously share the finitude of the books in which they occur - we are not tempted to think that by adopting an attitude toward them we have adopted an attitude toward every possible sort of person. By contrast, books which are about ideas, even when written by historicists like Hegel and Nietzsche, look like descriptions of eternal relations between eternal objects, rather than genealogical accounts of the filiation of final vocabularies... 
This seems to be completely in line with the above. But the main point follows later, in the footnote below:

There are, of course, novels like Thomas Mann's Doktor Faustus in which the characters are simply dressed-up generalities. The novel form cannot by itself insure a perception of contingency. It only makes it a bit harder to avoid this perception. 60

So, a few novels contain some elements that do not meet the requirements of the pluralistic narrative. Namely, the description of characters might retain something from the failed legacy of essentialism in some stories, and these works are excluded from Rorty's canon. Presumably, their author does not give his/her cast the freedom the form of the novel would provide them. Instead of allowing them to follow their own lights, the writer directly uses this cast to put already existing plan into action. He/she is using them as the spokesmen of his/her own ideas. Now, this point must be the residue of something significantly larger. Generalist character traits cloak other features of fiction that go against the liberal interpretation of the genre. In this light, it seems obvious that the problem goes well beyond ill-fated types. When Rorty turns Doktor Faustus down for the incontingent features of its figures, he is dismissing the frame of the Mannian universe as a whole for being not sufficiently incidental and ironic. The description of characters takes up a huge share in constituting the general form and the content of the work. The inhabitants of a fictional society, they constitute the world of the novel by revealing their persona in their thoughts and deeds. A character - the "form" of a person - gives form to what is happening in the novel. It essentially implies the changes of the given individual's inner field and his/her actual action. Generalist features cover similarly determined attitudes. Therefore, these "dressed up generalities" will induce a pre-schematised, ascertained line of events, and Rorty's contempt for a few character traits must be covering his critique of these characters' story, too. Broad properties will probably require generalised action schemes. Objection to the contents of a character leads to a censure on the formal apparatus of the story. Rorty's "theory" would find faults with a number of suspicious plot schemes that, similarly to the characters, keep something back from essentialist thinking.

There seems to be a connection between essentialism incorporated in certain character traits and Rorty's indirect rejection of some important notions

${ }^{60}$ Rorty. Contingency, Irony, and Solidarity, p. 108. 
in Aristotelian poetics. It must be plots not following the liberal call for showing rather than telling that develop essentialist types and are to be ignored. A few kinds of novels can keep something of suspicious theoretism. The "web of contingencies" offered by the framework of the genre does not necessarily neutralise heavy theoretical content. If necessity culminates on a very high level in the story, (on account of its intellectual theme the plot of the novel should necessarily and dynamically develop into a single direction) then there is no time for the liberal ironist to realise his/her goals in genre. ${ }^{61}$ The impetus of the story has a striking resemblance to the dynamism of desire-governed discourses. Therefore, Rorty does not dignify all sorts of fiction.

There are, indeed, such novels. Quite a few books have a clear, essentially directed frame, which requires characters to act in accordance with the line of narration. Just take another novel from another culture, Dostoevski, for instance. Compare the value-governed, richly ornamented, moralising world of his characters to the analytic, "well-balanced" and democratic aura of Dickens. Compare their "speed," their dynamism, see how the actual story affects their style, and the difference may become explicit. Furthermore, compare them on the basis of the notion of necessity, that is to say, see if there is any difference between them as far as the "weight" of their theme is concerned. As opposed to the Dickens of a famously sober, analytic English mind, one can find totally different phenomena in this story influenced by a different spirit; one may also get a view on say, the grandiose ideas of the Slavophiles at the time. Even though Dostoevski, in Bakhtin's view, seems to be highly devoted to the pluralism of the genre and the polyphony of his works could be hardly contested, the rhythm, the dynamics of his narrative definitely differ from that of Dickens. Necessity culminates on a very high level in his works - it demands a strict and tense sequence of action. Beyond doubt, things cannot happen in them randomly; there could be serious reasons - hidden causes, essences, values, and theoretical beliefs of the various turns in the line of narration. The writer, while designing the story, gives priority to certain things: he does not consider the principles of democracy when it comes to deciding on, say, killing or keeping alive a certain character.

Therefore, fiction in its mere form cannot meet the requirements of pluralism. False idealism may leak into it in a way or another, and the pragmatist is inclined to reduce the risks that the narrative implies. When interpreting a work, he tries to pacify the line of telling. Since he has to regulate the plot of the

${ }^{61}$ In the concrete reception of the work, the novels may of course retain their pluralistic facet. 
story as well, he creates a politically correct theory of the novel by cleansing it of all suspicious scratches. He chooses a special set of novels and novelists to defend his point. Less and less remains of the pluralistic structure of the novel. Theoretical oddities do not directly dissolve in the carnival of the genre. Rorty does not favour the novel as he seems to do; he rather curbs the supremacy of the genre to which he attributed a distinguished position before. The seeds of metaphysics are likely to be implanted in the novel.

Yet, Rorty's tenets should be appreciated, not dismissed. ${ }^{62}$ As indicated in the beginning, empathy as such might be a useful means of treating his thinking. Certainly, it would be easy to denounce pragmatic liberalism for being an absolute stranger in the realm of literature, still, its challenge will remain valid. However hard one tries to defend fiction, Rorty's claim to eliminate the grand narrative of art and reduce pain sounds compelling, what is more, alarming. One had better stand up to the challenge of Rorty's program. The question is how Dickens the social thinker could be identified with the artistic visionary. It might be necessary to balance the quasi-essentialist structure of the dismissed novels with Rorty's call for contingency, irony, and solidarity.

Where is the dividing line between a "visceral" conception of art that creates grand narratives and a deliberately vague, pragmatic, politically correct idea? Can there be balance in the novel between plurality and essentiality?

\section{A RORTYANISED KUNDERA}

In order to answer the questions above, one might not want to go too far. All the more so, as, interestingly, Rorty's system depends on the modification of another substantial argument - he relies heavily on someone else's work. His pragmatic conception of the novel largely feeds on the thoughts of a distinctly European novelist: Milan Kundera. Concerning the philosophical consequences of the genre they practically hold the same views; a quasi-political and anti-essentialist interpretation of the novel is totally acceptable to both men.

The novel's wisdom is different from that of the philosophy. The novel is born not of the theoretical spirit, but the spirit of humour. One of

\footnotetext{
${ }^{62}$ I purposely do not want to blame Rorty for the negative aesthetic effects his theory might, in fact, have on fiction. Apparently, there is no point in attacking the American philosopher, as one would only reaffirm his devastating view on grand narratives, and make him/herself ridiculous.
} 
Europe's major failures is that it never understood the most European of the arts - the novel; neither its spirit, nor its great knowledge and discoveries, nor the autonomy of its history. The art inspired by Gods's laughter does not by nature serve ideological certitudes: it contradicts them. Like Penelope, it undoes each night the tapestry that the theologians, philosophers and learned men had woven the day before. [...] The eighteenth century is not only the century of Rousseau, of Voltaire, of Holbach; it is also (perhaps above all!) the age of Fielding, Sterne, Goethe, Laclos. ${ }^{63}$

In these lines, one might reconsider how - instead of drawing some obscure, fuzzy analogies with sophisticated metaphysical concepts - great novelists have helped one to achieve the goals of the liberal ironist. Kundera's claim on the basic mission of the genre fits entirely the facet of the "democratic narrative."

Nevertheless, there are a few points here that can hardly be attributed to Rorty. Admittedly, the author of Philosophy as a Mirror of Nature constructs his theory on Kundera's teaching by "correcting" it a bit at the same time. Rorty reads The Art of the Novel in his own manner. Even though a clear-cut correspondence could be lined up between their standpoints, as regards the background of their thinking it would be much harder to point out any similarities. Actually, the sequence of argumentation is of high importance in their works: each author follows different traits on their way to fiction.

Before Kundera touches upon the anti-essentialism issue, he embarks on a cardinal philosophical enterprise of the turn of the century: the work of Edmund Husserl and his pupil, Heidegger. Kundera deals with an overall crisis at the first place, in which "the one-sided nature of European sciences, which reduced the world to a mere object of technical and mathematical investigation" ${ }^{\text {"64 }}$ marks the epoch. The Czech-French writer shows how great Husserl had held the disaster of objectification: the human being having conquered the world has eventually lost himself in something similar to the forgetfulness of being debated by Heidegger. As sciences excluded die Lebenswelt, the Cartesian mind gradually eliminated the heritage of humankind thereby expressing the extreme need for a progressive theory to account for this dilemma at the time.

\footnotetext{
${ }^{63}$ Kundera, p. 60.

${ }^{64}$ Rorty. "Heidegger, Kundera and Dickens," p. 76.

${ }^{65}$ Kundera, p. 4.
} 
And there is Kundera's far-reaching proposal, which as regards one of its goals at least would surely be appreciated by Rorty:

Perhaps it is Cervantes whom the two phenomenologists [Husserl and Heidegger] neglected to take into consideration in their judgement of the Modern Era. By that I mean: If it is true that philosophy and science have forgotten about men's being, it emerges all the more plainly that with Cervantes a great European art took shape that is nothing other than the investigation of this forgotten being. ${ }^{66}$

This certainly reminds us of Rorty's preference for the novel over philosophy in a different packaging. Rorty must be highly content with the glorious role Kundera attributes to the artistic. Nonetheless, one may as well recognise the tone so characteristic of Kundera; some words would undoubtedly give pain to Rorty. On account of the last statement of our quotation it is not clear why the author talks about "analysing this forgotten existence" in such a context. Truly, should one continue reading Chapter 2, doubt might arise concerning Kundera's "liberal" understanding of Cervantes' heritage.

Indeed, all the great existential themes Heidegger analyzes in Being and Time - considering them to have been neglected by earlier European philosophy - had been unveiled, displayed, illuminated by four centuries of the novel [...]. In its own way, through its own logic, the novel discovered the various dimensions of existence one by one...

Apparently, Kundera also discredits philosophy because it has not been capable of carrying out its undertaking. However, his neglect of the theoretic has its roots in something significantly different. As opposed to Rorty, who applauds the novel's absolute independence, the author of The Art of the Novel connects fiction to Husserl's legacy. It is only from this point that he goes on to debating the plurality of the novel. Kundera does not state it explicitly, yet the logic of this text tells us: there lies an essential connection between the eradication of objectivity and the liberal perspectives of the novel. According to Kundera, from the beginning of Modern times the novel has understood its mission as protecting man in its scientific and spiritual adventures from the "termites of reduction" 68 to throw light on the "concrete world of life" defined by Husserl. The novel

\footnotetext{
${ }^{66}$ Kundera, p. 4.

${ }^{67}$ Kundera, p. 5.

${ }^{68}$ Kundera, p. 17.
} 
attempted to get back to what has been lost in experience - it tried to bypass alienation. For the wisdom of the novel shows: by saving "being" from falling into complete oblivion, one might cut out the clichés and oversimplifications of this estranged world. By escaping from the "whirlpool of reduction," 69 one could get away from the conventionalism of a science and technology-conducted culture. This all looks to be indispensable so as to see clearly and not accept the rule of one's surroundings. Therefore, according to Kundera, plurality requires an antecedent: the recaptured wholeness of the phenomena in the novel may cut out the dominance of essentialism.

For Kundera the spirit of the novel involves the spirit of freedom. He builds the core of his poetics on the moral of the novel, though this conception of ethics in literature should be significantly different from that of Rorty. As Herman Broch, summarising the thesis of Kundera's book, states:

The sole raison d'etre of the novel is to discover what only the novel can discover. A novel that does not discover a hitherto unknown segment of existence is immoral. Knowledge [getting to know something unknown] is the novel's only morality.

All in all, Kundera's view seems to go beyond the tenets of liberal pragmatism. Rorty does not hesitate to tackle this quasi-phenomenological reading of the genre. The grave speech of phenomenologists cannot stand the test; it should straightforwardly go in the category of grand narratives. According to Rorty, a pluralistic interpretation of the novel here is supposed to be compatible with "essentialism," because the Czech thinker "politely interprets his [Heidegger's] term "forgetfulness of being" as meaning "forgetfulness of this essential relativity." "Y1 Yet, this cannot work. He turns the idea down by solely reasserting his earlier thesis on how the novelist and the "philosopher of poetry" cannot have anything in common.

Here at the beginning of his book, Kundera thinks of Husserl's Lebenswelt and Heidegger's In-der.Welt-Sein as standing over against "the one-sided nature of the European sciences, which reduced the world to a mere object of technical and mathematical investigation," and casually assimilates both to his own notion of the "essential relativity of human

\footnotetext{
${ }^{69}$ Kundera, p. 17.

${ }^{70}$ Kundera, p. 16.

${ }^{71}$ Rorty. "Heidegger, Kundera and Dickens," p. 76.
} 
affairs." But this assimilation is misleading. Husserl and early Heidegger were insistent on getting down to the basic, permanent structure of the Lebenswelt, or of the In-der.Welt-Sein. For Kundera, we make up this structure as we go along.

So, the pragmatist cleans the othewise serviceable theory from the slips of his companion in order to utilise it again. By contrasting the plurality of the novel with the basic, permanent structure of the Lebenswelt, or of the In-der-Welt-Sein, Rorty assumes that a democratic interpretation of the genre has nothing to do with Husserl, or, obviously, Heidegger. Apparently, in the noisy, uproarious world of the novel it would be pretty painstaking to rely on such ascetic priests.

\section{THE PLOT AND THEME: KUNDERA'S HISTORY OF INVITATIONS}

This being granted, there is a growing need to view Kundera's ars poetica in greater depth. It is to be deliberated whether Kundera's cunning theory of the novel can successfully account for the simultaneous assignments of political correctness and a reasoning aiming at the essential structure of things. Kundera's idea that the novel could co-ordinate the pluralism argument with the permanent structure of consciousness requires an explication.

Kundera does his best to reconcile plurality with the principle of viewing/showing the essential structures of the concrete world of life. Nothing models this hypothesis more effectively than his speculation on the art of structuring the novel. According to Kundera, the genre ought to have a sort of tendency towards a substantial spiritual content, its form compels the author to aim at the heart of the matter. In Kundera's words, it has to be made dense. Kundera develops a certain aesthetic strategy; he hopes to implement his technique in story-telling as follows:

I have always constructed them on two levels: on the first, I compose the novel's story; over that I develop the themes. The themes are worked out steadily within and by the story. Whenever a novel abandons its themes and settles for just telling the story, it goes flat. ${ }^{74}$

\footnotetext{
${ }^{72}$ Rorty. "Heidegger, Kundera and Dickens," p. 76.

${ }^{73}$ Kundera, p. 73.

${ }^{74}$ Kundera, p. 83.
} 
In other words, Kundera conceives of a topic which he combines, with the line of the narrative. Now, it is utterly important to see that he lays the emphasis on the presence of a clear-cut thematic; he thinks that only by strengthening the intellectual apparatus of the work - by developing an abstract thesis - can one create a successful novel. This idea may seem suspicious for a moment, as it may suggest that the ascetic priest hiding behind the storyteller again. But he does not simply add this "existential thematic" to the already existing frame of the story as one puts a cloak on a dead corpse or plasters a bouses with mortar. He makes it part of the novel. As Kundera says, "Once it is part of a novel, reflection changes its essence: a dogmatic thought turns hypothetical. This is something philosophers miss when they try to write a novel." ${ }^{75}$ In other words, one cannot regard this move of Kundera as a revolt against fiction. On the contrary, it is the story that gives full significance to the theoretical; only narration supplies the ideal with a semantic entirety. Only the narrated, that which provides a context to the sequence of happenings, seems to be the proper manifestation of cognitive functions. In its intentional structure, the story as such implies an element that can stop the laughter of deities.

It is not all by accident that Kundera talks about an inherent connection between theme and story. As defined in his small dictionary of key words, the novel meditates over the great themes of existence, which are voiced through experimental selves, ${ }^{76}$ and this explanation necessarily reveals the Heideggerian affiliations of the theory. If the most important Heideggerian terms are considered, the category of In-der-Welt-sein provides a proper analogy. Accordingly, Kundera underlines the importance of the fact that one cannot get an exterior perspective over things in the great story of being, for one does not view the world as the subject refers to the object. The world is part of men, just as men is part of world, its primary dimension, and as the world changes so does existence (in-der-Welt-sein). ${ }^{77}$ So, most importantly, one has to interpret the underlying thematic of life from life itself. ${ }^{78}$

\footnotetext{
${ }^{75}$ Kundera, p. 79.

${ }^{76}$ Kundera, p. 142.

${ }_{77}$ Kundera, p. 35.

${ }^{78}$ This Heideggerian idea could be applied to Aristotle in an interesting way. Just as one cannot step out of being, the novelist obviously cannot go for the position of the historian, the student of historical facts. As one is fundamentally bound to one's existence - like "the snail to its shell" -, one can get knowledge of being from being in this story. Consequently, the story reveals an essential thematic, because the tale does not analyse the reality of history, but focuses on the fictitious. It does
} 
As a consequence, in Kundera's interpretation the aesthetic as such plays a decisive role; it is form that is supposed to integrate the essential into the pluralism of story telling. "But in art, the form is always more than a form. Every novel, like it or not, offers an answer to the question: what is human existence, and wherein does its poetry lie?"79 For Kundera ventures to balance the immense weight of his questions with the extreme contingency of the arrangement of those ideas. ${ }^{80}$ On the one hand, the contrast of an easy technique and a serious topic may reveal the "unbearable lightness" and insignificance of some phenomena of our ordinary life. "The union of a frivolous form and a serious subject lays bare our dramas $[\ldots]$ in all their terrible insignificance. ${ }^{\prime 1}$ This must be the implicit humour of the novel. At the same time, one should not forget that all of this is done in hope of approaching the essential, in the "positive" sense of the word. Narration, by redressing theory can carry out such an operation. ${ }^{82}$ Besides the humorous, the laughable, the story may also reveal some hidden, unexpected aspects of the theoretical. It may bring the abstract to a state in which it gets an unspoken yet extensive form of meaning.

On the whole, Kundera's strategy to thematise ultimate, permanent structures of consciousness in story telling incorporates a need to mediate between the stable scheme of the Lebenswelt and the plurality of the novel, and he finds the means of resolving this necessity in the intentional basis of the narrative. As, if one wants to, in the story one can give a phenomenological interpretation of plurality. The essential relativity of our underlying perspectives can be intelligible in the tradition set up by Husserl. How does the narrative approach the concrete world of life - what is the phenomenal structure of narrativity like exactly? Apparently, the story does not reveal anything explicitly; even if some particulars seem to turn to us, they disclose themselves at once. As a whole we cannot get to know the objects of our intentionality. Kundera states, talking about Dostoevski's Devils: "In each of the narrative lines, this theme is considered from a different

not engage in what happened, but considers what could be happening. This way, it throws a glance at the possible constitutions of the act. That is to say, in Kundera's words, it uncovers the possibilities of a human being. It reveals our existence. "Novelists draw the map of being by discovering this or that human possibility" (Kundera, p. 42).

${ }^{79}$ Kundera, p. 161.

${ }^{80}$ Kundera, p. 95.

${ }^{81}$ Kundera, p. 96.

${ }^{82}$ Kundera, p. 122. 
angle, like a thing reflected in three mirrors. ${ }^{~} 83$ That is, one cannot own the phenomenon, as it has many forms of apparition but not an ultimate one. ${ }^{84}$ Similarly to a search for the fundamental identity of the ego, Kundera discourages one from pursuing exaggerated optimism. In his view, "in a paradox: The more powerful the lens of the microscope observing the self, the more the self and its uniqueness elude to us.... ${ }^{85}$ And the feeling that remains will resemble a "paradoxical dissatisfaction," in as much as one will not be able to do anything except admit that the object has been examined from all possible angles.

In fact, here one may comprehend the unfixable movement of sensory data. In the essential relativity of perceiving phenomena, the diversity of aisthetic impressions comes to the fore. As quoted by Béla Bacsó from Wolfgang Welsch's analysis of Aristotle, "the sensory impressions are created exactly by the transferring of this manifold-complex into the simple (sensory, absolute, irreversible) - and that is where from it gains significance." ${ }^{\prime 88}$ One may engage in the constant displacement of our sensual world. Thus, one may understand where the phenomenological roots of the story lie. Apparently, in narration the very same processes are to be found working. ${ }^{89}$ The story simply gives way to the unreconcileable movements of our impressions. As Paul Ricoeur maintains, on the level of the genre an interaction is postulated between our pragmatic wisdom of life from the past and our realisation of a surprising element in the present. The paradox of the novel exploits this split between phronesis and synesis when something unusual turns up, to which one was not looking forward. However, this cannot be any disappointing to the devotees of theory, for if one understands the premises and consequences of such thesis, one would cope with a philosophical explication of the novel: 90

Philosophy will happily return its responsibility to other people - we will no more think ourselves the "functionaries of mankind" (Husserl), that is, we shall less likely want to think in the place of them - so that

\footnotetext{
${ }^{83}$ Kundera, p. 82.

${ }^{84}$ One should think of such Husserlian categories as "die Abschattung" and "passive synthesis."

${ }^{85}$ Kundera, p. 25.

${ }^{86}$ Kundera, p. 25.

${ }^{87}$ In the original, Greek meaning of aisthesis.

${ }^{88}$ Béla Bacsó. "A regényes élet." Határpontok. Budapest: T-Twins-Lukács Archívum-Századvég, 1994 , p. 165.

${ }^{89}$ Bacsó, p. 166.

${ }^{90}$ Bacsó, p. 166.
} 
one could, based on one's phronetical wisdom, weave the unexpected event into the already existing, well-known texture of life. ${ }^{91}$

Subsequently, such a theory drives our attention towards the history of the genre. $^{92}$ In the life of the novel every single narrative has had a special underlying structure, the uniqueness of which makes itself identical to others. Every simple work has been a trial for the mind to get closer to the empirical matter of the world. Thus, each of them must be equal in the history of the novel; they take part in boundless attempts of consciousness. For the novelist executes his assignment in the context of the specific age - up to the needs of the specific age. The novel thematises the Lebenswelt in an always regenerating form. The chronicle of the novel consists of an immense flow of "invitations." Kundera distinguishes four of these: an "invitation for the game" in the work of Diderot and Sterne; an "invitation for the dream" in Kafka's "enormous discoveries"; an "invitation for thinking" as regards the ambition of Musil and Broch to make the novel the highest spiritual synthesis; and "invitation to time," the commitment of Proust and Fuentes, Aragon, just to mention the most recent ones.

\section{A GRAND DIALOGUE}

Bleak House can be interpreted on the basis of Kundera's theory of the novel. When put in the above-mentioned line of "invitations" the work attains a new

\footnotetext{
${ }^{91}$ Bacsó, p. 166.

${ }^{92}$ Nonetheless, there is a point to be made here. Since, as a rejoinder to an earlier question, it follows from this theory that one may conceive of very many types of stories. In the history of the novel, there must be an infinite number of configurations that would meet the "standards" of Kunderaian poetics. As debated above, the genre has only one commitment. As long as a work in a way or another cultivates the moral of the novel, it should fit in the canon. If the basic Aristotelian principles of narration can be accepted, a relatively free system will be created. Kundera's essay does not attempt to legitimise a rigid scheme at all. The fact that he derives his ars poetica from an ontological reading of phenomenology does not give priority to the stories of being. (The most important distinction between Kundera's and Heidegger's philosophy could be described by the antinomies of ontic versus ontologic. In other words, Kundera's scheme is a pragmatic, popularised version of the phenomenologis.) Having read The Art of the Novel, one might falsely expect Kundera to compose a new order, the members of which even in their sujet incorporate existentialist narratives. In fact Kundera does not fall in that mistake. He does not levy new restrictions on the novel. By forming a relatively pluralistic model he accepts any work that as a whole serves his main goal, the analysis of being. This principle is as liberal as it can be on the level of the work: it acknowledges of any piece that serves artistic purposes with the means of the artistic.
} 
meaning. All in all, one may easily read the novel in the light of Rorty's principles; he is right in saying that a significant undertaking of Dickens' work lies in its critical functions. As mentioned before, the Aristotelian power, the impulse of the novel is eliminated. Instead of it, investigation, the slowness of analysis is accentuated. The reader should stay still, as it is the sight that becomes emphasised, not the story. $\mathrm{He} / \mathrm{she}$ is supposed to meet, to see a lot of people he/she cannot pass by: he/she has to honour them with his/her gaze, with sincere curiosity. That is how in the realm of the democratic one should respond to one's fellows. On the metaphorical level of the work, there is the emblematic fog to remind the reader of the unusual status quo of the work: it will cool down any hazy involvement that would, instead of engaging in the narratives of our counterparts, be drawn in by the story.

At the same time, Rorty's principles ought to be reconsidered to make a successful reading strategy of them. On a slightly different basis one can interpret it as a writing uncovering the misdeeds of human foolishness. For the work properly shows what realism entails in fact, and without understanding it, one may hardly appreciate Dickens' art. Realism, the realistic presentation of social relations, the criticism of human conditions on the level of the work should not be sufficient; a critical function of the work remains totally blunt and misunderstood, if one does not realise what lies behind this as well. In Bleak House, the realism of social phenomena requires the realism - the looking behind, the exploring - of physical phenomena, too. In the thickly woven texture of the book democratic ideology carries a phenomenological background. Since one should not take anything as one can see it; things are not simply projected to us as one would wish. The underlying structure of phenomena moves us out of the stable relation of the subject to the object. One has to look behind, and scratch the background of things. In order to conceive of the affairs of human partnership, the evanescent element that is constantly deceiving our senses should not be ignored. In forming our judgements one needs the ungraspable, the differing implied in the phenomenaltiy of things. By emphasising seeing, a spotlight is thrown on the imagery. The pervading silkiness, the horrifying affects of the fog are definitely needed to interpret the world of the cold Victorian era; the reader has to get into the visual so as to grasp the reality of sensual data. ${ }^{93}$ This

\footnotetext{
${ }^{93}$ Husserl, and his disciples, to some extent, focus on the 'familiar' phenomena of our life-world If my analysis is not mistaken, Dickens' emphasis on the "romantic side of familiar things" in the preface in the 1892 edition (Dickens, p. 9.) may gain a new interpretation. In a quasi-hermeneutic
} 
is why the viewer of Bleak House becomes aware of the democratic values of the novel and apprehends the intolerable situation of bureaucracy and the social conditions of the age.

Therefore, Rorty seems to confuse the result with the cause. The comme il faut of the novel may explain a lot, but it is another issue to argue for a personal commitment to the principles of democracy in the work. One may opt for a politically correct explication of the genre; however, in praxis, within the boundaries of the lively microcosm of the novel, one should primarily reveal the particular motivation of the individuals behaving democratically and only then interpret it in the spirit of political decorum. Instead of following the directives of a specific theorem, the devotees of democracy would rather read individual stories that uncover the hidden, but all the more essential networks among people. The novel cannot be a mere model of politics, but a source of human relations that gives rise to the political.

Only this can help us to appreciate the diversities and the idiosyncrasies of the characters of the novel. Thus, by engaging in the milieu of the work, the reader may as well take pleasure in looking around here; he/she will not even become conscious of the actual time spent when reading it. And Kundera provides for an analogy here again. He says:

The answer can be found in a letter [...] to Milena: "The office is not a stupid institution; it belongs more to the realm of the fantastic than of the stupid." This sentence contains one of Kafka's greatest secrets. He saw what no one else could see: not only the enormous importance of the bureaucratic phenomenon for man, for his condition and his future, but also (even more surprisingly) the poetic potential contained in the phantasmic nature of offices.

And a little later:

The quality of the fantastic that he perceived in the bureaucratic world allowed Kafka to do what has seemed unimaginable before: he transformed the profoundly antipoetic material of a highly bureaucratized society into the great poetry of the novel [...] into myth, into epic, into a kind of beauty never before seen. ${ }^{94}$

phenomenology of romanticism, Bleak House implies a few vague similarities between the two lines of thought.

${ }^{94}$ Kundera, pp. 113-114. 
Here another hint is given at the radical autonomy of the novel, ${ }^{95}$ as the viewer might witness how a social, political analysis can be completed in the text of the work. It seems understandable that the genre has a special advantage over other means of reporting of facts. In its form it helps to convey the theme - that which can only be told by the novel.

To sum up, it could be stated that the main metaphors of the book arouse the dispute between phenomenology and pragmatism. Apart from the apparent parallels, I tried to find the differences between these two theories, and locate the more appropriate conception to form a theory of the novel. Choosing between the two stances, I argued for a phenomenological interpretation of the theory of the novel. I attempted to disclose a few interesting critical aspects of the genre. As argued by Kundera, it is not at all unlikely that a grand dialogue took shape between the novel and philosophy. "The novel is built on [these] categories as a house is built on pillars."

\footnotetext{
${ }^{95}$ Kundera, p. 117.

${ }_{97}^{96}$ Kundera, p. 161.

${ }^{97}$ Kundera, p. 95.
} 